\title{
PEMANFAATAN SITUS PRASEJARAH GOA KAMPRET SEBAGAI SUMBER BELAJAR SEJARAH BAGI SISWA SMA SWASTA SWAKARYA KABUPATEN LANGKAT
}

\author{
Oleh: \\ Ika Purnama Sari \\ Juliani
}

\begin{abstract}
ABSTRAK
Penelitian ini bertujuan untuk mengetahui sejarah Situs Goa Kampret di Desa Bukit Lawang, serta memanfaatkan Situs Goa Kampret sebagai sumber belajar sejarah bagi siswa SMA sesuai Kurikulum 2013. Untuk memperoleh data-data tersebut, maka peneliti menggunakan teknik pengumpulan data berupa angket, LKS, observasi, studi pustaka, wawancara yang berkaitan dengan objek penelitian/judul skripsi. Dari hasil penelitian yang peneliti lakukan Situs Goa Kampret merupakan peninggalan dari aktifitas manusia pada zaman praaksara yaitu pada periode masa mesolitikum sampai ke neolitikum. Hal ini dibuktikan dengan ditemukannya artefak yang menunjukkan ciri budaya mesolitik (kapak batu) sampai kepada ciri budaya neolitik (gerabah). Selain itu sebaran situs ini diindikasikan berbudaya Hoabinh.
\end{abstract}

Kata kunci : Situs Goa Kampret, sumber belajar sejarah 


\section{PENDAhuluan}

Situs adalah lokasi yang berada di darat atau di air yang mengandung Benda Cagar Budaya, Bangunan Cagar Budaya, dan Struktur Cagar Budaya sebagai hasil kegiatan manusia atau bukti kejadian pada masa lalu. Maka dari itu situs harus dilindungi, dipelihara dan dilestarikan.

Berdasarkan dari hasil penelitian yang dilakukan oleh tim Balai Arkeologi Medan dengan melakukan penggalian (ekskavasi) oleh Ketut Wiradnyana dkk pada tahun 1999: Terdapat Situs Hoabinh yang ditemukan di dataran tinggi letaknya di Desa Bukit Lawang, Kec. Bahorok, Kab. Langkat tepatnya di lereng pegunungan Bukit Barisan. Situs yang terletak pada ketinggian 180 mdpl ini berada di sekitar Goa Kampret. Menyisakan tinggalan alat batu yang memiliki ciri morfologis dan teknologis sama dengan budaya Hoabinh. Keletakan Goa Kampret berada pada lereng pegunungan Bukit Barisan dan di sekitarnya berupa lingkungan hutan dengan Sungai Bahorok yang berjarak sekitar 100 meter. Yang merupakan kehidupan manusia pada masa Praaksara pada zaman Mesolitik.

Dengan adanya situs tersebut selain sebagai objek pariwisata dapat juga dimanfaatkan sebagai sumber belajar sejarah dalam materi "Mengidentifikasi Tradisi Masyarakat Indonesia Pada Masa Praaksara”. Dimana dalam Kurikulum di tuntut untuk mebangun landasan bagi perkembangan potensi peserta didik. Untuk mendukung terwujudnya proses pembelajaran tersebut, maka situs Goa Kampret yang terletak di Desa Bukit Lawang ini bisa dimanfaatkan sebagai sumber pembelajaran sejarah guna untuk menambah wawasan baik untuk orang yang berlingkup pada instansi pendidikan maupun masyarakat umum, dengan melakukan kunjungan langsung ke situs Goa Kampret yang terletak di Desa Bukit Lawang. Peserta didik atau siswa/i dapat melihat dan merasakan gambaran dari kehidupan manusia pada masa praaksara serta mengetahui dan memahami secara jelas bagaimana kehidupan manusia pada masa praaksara. Mengingat menentukan strategi pembelajaran adalah suatu hal yang penting bagi proses belajar mengajar agar terwujudnya pembelajaran yang efektif. 
Dalam proses belajar mengajar ada saatnya siswa perlu diajak keluar sekolah, untuk meninjau tempat tertentu atau obyek yang lain. Hal ini bukan sekedar rekreasi tetapi untuk belajar atau memperdalam pelajaran dengan melihat kenyataannya. Karena itu dikatakan sebagai karya wisata ialah cara mengajar yang dilaksanakan dengan mengajak siswa ke suatu tempat atau objek tertentu di luar sekolah untuk mempelajari/menyelidiki sesuatu seperti meninjau museum, situs dan perkebunan. Dalam pemanfaatan sumber belajar ini maka dapat diambil contoh misalnya situs, apabila kita mau menggunakan situs sebagai sumber belajar tidak mungkin membawa situs tersebut ke dalam kelas, oleh karenanya kita harus mendatangi situs tersebut.

Dalam Implementasi kurikulum Siswa dituntut untuk paham atas materi artinya melihat bagaimana kemajuan peserta didik, siswa dafat aktif baik fisik, mental maupun sosial. Kurikulum memainkan peran yang sangat penting dalam mewujudkan generasi yang handal, kreatif, inovatif, dan menjadi pribadi yang bertanggung jawab. Upaya penyempurnaan kurikulum tidak lain, demi mewujudkan sistem pendidikan nasional yang kompetitif dan selalu relevan dengan perkembangan zaman yang senantiasa menjadi tuntutan.

Untuk menjawab permasalahan di atas, diperlukan suatu upaya untuk mengatasi keterbatasan pembelajaran sejarah yang selama ini terjadi yaitu salah satunya dengan memanfaatkan situs Goa Kampret sebagai sumber belajar sejarah. Ada dua cara dalam memanfaatkan fasilitas dan sumber belajar dalam menyukseskan implementasi kurikulum. Pertama: membawa sumber belajar kedalam kelas dan kedua: membawa kelas ke lapangan tempat sumber belajar berada.

Dalam pemanfaatan sumber belajar yang kedua ini maka dapat diambil contoh misalnya situs, apabila kita mau menggunakan situs sebagai sumber belajar tidak mungkin membawa situs tersebut ke dalam kelas, oleh karenanya ita harus mendatangi situs tersebut. Pemanfaatan sumber belajar dengan cara yang kedua ini dapat dilakukan dengan metode karyawisata, hal ini dilakukan terutama untuk mengefektifkan biaya yang dikeluarkan. 


\section{PEMBAHASAN}

\section{A. Sejarah Situs Goa Kampret}

Pada masa kala Plestosin manusia masih hidup dengan berburu dan mengumpulkan makanan dan manusia itu mulai hidup menetap dan umumnya di Indonesia goa merupakan pilihan utama untuk bertempat tinggal. Manusia yang bertempat tinggal di dalam goa-goa menghasilkan sesuatu yang baru yang belum dihasilkan pada masa sebelumnya yaitu berupa lukisan dan goresan goa. Selain bertempat tinggal di goa ada juga yang bertempat tinggal di ping gir laut dengan mengeksploitasi kerang laut sebagai makanan utama.

Sejalan dengan kecerdasan otak manusia yang semakin berkembang, maka keterampilan manusia dalam mengolah bahan-bahan alam semakin maju pula penggunaan alat-alat batu untuk berbagai keperluan sehari-hari juga mengalami perkembangan dan variasi dalam penggunaan. Alat-alat serpih bilah merupakan alat utama yang utama disamping alat dari kayu dan kulit kerang. Dilihat dari dinginnya iklim dan keamanan maka goa merupakan pilihan utama untuk hunian dan tinggal menetap ini mempengaruhi cara hidupnya yang sebelumnya.

Sungai merupakan salah satu faktor penting dalam kehidupan manusia praaksara, mengingat air dan batu adalah unsur penentu dalam aktivitas kehidupan manusia. Oleh karen itu keduanya dapat dijadikan indikasi dalam mencari sisa-sisa kehidupan manusia pada masa lampau. Situs hunian cendrung pada lokasi yang berdekatan dengan sumber air, bahkan sisa aktivitas manusia seperti peralatan batu banyak dijumpai pada lokasi tersebut.

Pada masa sekarang bekas-bekas perkampungan serupa apa yang tersebut di atas oleh para ahli prehistori disebut abris sous roches (tempat-tempat perlindungan di bawah karang). Tempat-tempat serupa itu merupakan karang-karang atau goa-goa dengan himpunan tanah pada dasarnya, yang mengandung bekas-bekas alat-alat berupa batu, tulang dan kerang dari zaman dahulu.

Alat-alat tersebut diatas pada umumnya digunakan untuk menebang, mengambil kulit kayu, membelah, menyerut, menggergaji kayu dan juga sebagai 
cangkul dalam usaha mengolah tanah. Pengusung budaya Hoabinh cenderung mempunyai perekonomian yang menekankan pada perburuan dan pengumpulan makanan di pantai dan pedalaman. Hoabinh cendrung ditemukan pada masa-masa sebelum tembikar.

Situs Hoabinh pada umumnya ditemukan di dataran rendah. Situs Hoabinh yang ditemukan di dataran tinggi letaknya di Desa Bukit Lawang, Kecamatan Bahorok, Kabupaten Langkat tepatnya di lereng pegunungan bukit barisan. Situs yang terletak pada ketinggian 180 mdpl ini berada di sekitar Goa Kampret. Menyisakan tinggalan alat batu yang memiliki ciri morfologis dan teknologis sama dengan budaya Hoabinh. Keletakan Goa Kampret berada pada lereng pegunungan bukit barisan dan disekitarnya berupa lingkungan hutan dengan Sungai Bahorok yang berjarak sekitar 100 meter.

Di Goa Marike, di Ceruk Bukit Lawang, di daerah Nomutongan di Bungara, di kebun sayur, dan di daerah Turangi yang arealnya tersebar di lereng sebelah Timur pegunungan bukit barisan dan masih berada di sekitar DAS Bahorok, Kabupaten Langkat, juga merupakan situs mesolitik dengan tinggalan peralatan batu yang memiliki ciri morfologi dan teknologi sama dengan budaya Hoabinh.

Keberadaan situs prasejarah di sekitar Bukit Lawang, Kabupaten Langkat, Provinsi Sumatera Utara banyak di informasikan oleh Mc. Kinnon: Selain sebaran situs yang diindikasikan berbudaya Hoabinh dengan ditemukannya artefak batu yang ditemukan di permukaan situs. Dari morfologis dan teknologi artefak batu yang ditemukan tersebut memiliki kesamaan dengan morfologi dan teknologi peralatan batu yang berbudaya Hoabinh. Adapun sebaran situs yang masuk ke dalam wilayah DAS Wampu adalah Ceruk Bukit Lawang, di daerah Kebun Sayur, Turanggi dan di Goa Marike.

Keberadaan Goa Kampret, di dekat Ceruk Bukit Lawang sebagai salah satu situs Hoabinh dataran tinggi yang penting diketahui dari hasil penelitian Balai Arkeologi Medan yang diantaranya menghasilkan beberapa kapak batu, fragmen tulang, dan fragmen gerabah yang merupakan sisa dari aktivitas manusia masa lalu. Kapak batu sebagai bentuk budaya material yang ditemukan di situs tersebut memiliki 
bentuk dan teknologi yang sama dengan kapak batu yang di temukan di situs Bukit Kerang di Kecamatan Hinai, Langkat. Dari sisa artefak dan ekofak yang sangat terbatas mengindikasikan manusia pendukung budaya Hoabinh di situs Goa Kampret tersebut memanfaatkan goa tersebut untuk digunakan yang bersifat hanya sementara yang kemungkinan berkaitan dengan aktivitas perburuan (menunggu binatang buruan).

Indikasi adanya estetika pada masa praaksara khususnya di dalam Goa Kampret yaitu dengan ditemukannya fragmen bibir gerabah di Goa Kampret yang memiliki bentuk melekung yang tidak terkait dengan fungsinya dan lebih mengarah ke estetika maka dapat dikatakan bahwa masyarakat penghuni Goa Kampret sudah mengenal estetika di dalam melangsungkan hidupnya.

Dengan adanya situs-situs Hoabinh di dataran tinggi tidak tertutup kemungkinan strategi adaptasi dilakukan dengan merubah pola hidup sehari-hari. Pola hidup dari mengumpulkan makanan (moluska) berubah ke pola hidup berburu. Hal ini di mungkinkan mengingat alam tidak setiap saat menyiapkan moluska mengingat moluska juga hidup tergantung pada kondisi alam.

Berdasarkan paparan diatas dapat disimpulkan bahwa konsep Situs Prasejarah Goa Kampret yang dimaksud dalam peneliti disini adalah lokasi yang memiliki sebuah peninggalan bersejarah dari masa mesolitik sampai ke masa neolitik berupa artefak, tulang belulang dan gerabah yang diindikasikan berbudaya hoabinh yang menunjukkan adanya kehidupan serta menjadi tempat aktifitas manusia pada masa lampau.

\section{B. Temuan Goa Kampret Berdasarkan dari Hasil Ekskavasi: \\ 1. Artefak Litich}

Dari 11 artefac litich yang ditemukan pada tahun 1999 baik dipermukaan tanah maupun dalam lubang gali B2 didominasi dengan serpihan dari bahan andesit sebanyak 6 buah, 3 buah alat litik dan 2 buah batu monolit (kerakal). Serpihan yang ditemukan itu tipis, berbentuk lonjong dan tidak menunjukkan bekas pakai, hanya pada batu pukul menunjukkan bekas pakai melalui salah satu ujung batu yang berbentuk 
lonjong berupa kerusakan yang diakibatkan oleh penggunaan. Batu pikul tersebut berukuran tinggi $10,5 \mathrm{~cm}$ dengan lebar $7 \mathrm{~cm}$ dan tebal $4 \mathrm{~cm}$ terbuat dari bahan andesit.

\section{Tulang}

Ada 4 jenis tulang yang ditemukan pada penggalian kali ini yaitu sebuah fragmen tulang mamalia yang teridentifikasi sebagai tulang kaki belakang mamalia, 2 buah tulang ayam satu diantaranya sebuah tanduk yang sudah memfosil.

\section{Gerabah}

Fragmen gerabah yang ditemukan sebanyak 3 buah, 2 buah ditemukan pada lubang gali dan sebuah ditemukan pada permukaan. Gerabah yang ditemukan pada lubang gali sebuah diantaranya merupakan bagian bibir gerabah bewarna gelap keabuabuan dengan temper yang kasar. Pada bagian dalam dari bibir gerabah ini menunjukkan warna yang sama dengan bagian luar. Sehingga kemungkinan gerabah ini dibakar pada suhu yang sangat rendah sehingga partikel-partikel yang terdapat pada bagian luar gerabah tersebut tidak hancur. Bibir gerabah ini memiliki bentuk yang sudah bagus hanya saja teknologi pembakarannya masih kurang, hal terbut terlihat pada bentuk bibir gerabah dan partikel yang menempel diseluruh bagian bibir gerabah sehingga tampak fragmen gerabah tersebut masih kasar.

\section{Pemanfaatan Situs Prasejarah Goa Kampret Sebagai Sumber Belajar Sejarah di SMA}

Adapun cara yang dilakukan untuk memanfaatkan situs Prasejarah Goa Kampret sebagai sumber belajar sejarah bagi siswa SMA Swasta Swakarya sesuai Kurikulum 2013 adalah dengan membawa siswa/i melakukan kunjungan langsung ke situs Goa Kampret di Desa Bukit Lawang, Kecamatan Bahorok, Kabupaten Langkat. Kadang-kadang dalam proses belajar mengajar siswa perlu diajak keluar sekolah, untuk meninjau tempat tertentu atau objek yang lain. Hal itu bukan sekedar rekreasi, tetapi untuk belajar atau memperdalam pelajarannya dengan melihat kenyatannya. 
Teknik karya wisata ini digunakan karena memiliki tujuan sebagai berikut: dengan melaksanakan karya wisata diharapkan siswa dapat memperoleh pengalaman langsung dari obyek yang dilihatnya. Juga mereka bisa melihat, mendengar, meneliti dan mencoba apa yang dihadapinya, agar nantinya dapat menarik kesimpulan dan sekaligus dalam waktu yang sama ia bisa mempelajari mata pelajaran.

Agar penggunaan metode karya wisata dapat efektif, maka pelaksanaannya perlu memperhatikan langkah-langkah sebagai berikut :

1. Persiapan Awal.

a.Perumusan tujuan melakukan kunjungan ke situs Goa Kampret.

Perumusan tujuan harus jelas maksudnya adalah dengan melakukan kunjungan langsung ke situs Goa Kampret bertujuan untuk apa, kemudian bermanfaat atau tidakkah melakukan kunjungan ke situs Goa Kampret tersebut serta ada tidakkah kaitannya dengan materi pembelajaran sejarah disekolah dengan melihat berdasarkan kurikulum. Karena situs Goa Kampret merupakan bekas tempat tinggal aktifitas manusia pada masa mesolitikum sampai ke neolitikum dibuktikan berdasarkan peninggalan yang telah ditemukan jadi situs Goa Kampret berkaitan sesuai dengan K13 dengan Indikator Pencapaian: Mengidentifikasi Tradisi Masyarakat Masa Praaksara di SMA kelas X.

Jadi dengan diadakannya melakukan kunjungan ke situs Goa Kampret dalam hal ini siswa/i bukan dalam rangka rekreasi melainkan dalam proses belajar. Adapun tujuan dari diadakannya kunjungan ke situs Goa Kampret agar lebih menarik minat siswa dalam pembelajaran sejarah, siswa tidak hanya belajar dalam kelas melainkan dapat belajar di luar kelas dengan mengunjungi situs Goa Kampret agar siswa dapat melihat dan mengamati secara langsung gambaran dari kehidupan manusia pada masa praaksara. Dengan tujuan diharapkan siswa/i dapat memahamai sejarah situs Goa Kampret dan memahami bagaimana kehidupan manusia praaksara secara lebih dalam sesuai rencana pelaksanaan pembelajaran yang telah dibuat. 
b. Membuat surat izin mengadakan kunjungan ke situs Goa Kampret.

Sebelum melakukan kunjungan langsung ke situs Goa Kampret perlu menghubungi pemimpin dalam rangka meminta izin serta diharapkan dapat membantu berjalannya acara pada saat melakukan kunjungan ke situs Goa Kampret tersebut terlaksana dengan lancar. Agar nantinya berjalan dengan baik dan sesuai dengan perumusan tujuan diadakannya kunjungan ke situs Goa Kampret di Desa Bukit Lawang, Kecamatan Bahorok, Kabupaten Langkat.

c. Merumuskan pelaksanaan dengan matang.

Menyusun perencanaan yang matang dengan mempertimbangkan hari serta tanggal berapa kunjungan ke situs Goa Kampret dilaksanakan dengan tidak mengganggu pembelajaran yang lain. Membagi tugas dalam arti, guru bertanggung jawab penuh yaitu mengawasi maupun mengarahkan pada saat melakukan kunjungan ke situs Goa Kampret di Desa Bukit Lawang, Kecamatan Bahorok, Kabupaten Langkat dan siswa diberi tugas membawa perlengkapan seperti buku dan alat tulis kemudian senter dikarenakan didalam Goa Kampret sangat gelap dan diharpkan bagi siswi perempuan menggunakan celana olahraga.

Menyiapkan sarana disini mengingat situs Goa Kampret cukup jauh jaraknya dari sekolah SMA Swasta Swakarya yaitu dari Tanjung Langkat menuju Bukit Lawang maka perlu disiapkan transportasi. Kemudian makan, tempat istirahat juga harus dipersiapkan. Maka mengadakan kunjungan ke situs Goa Kampret menggunakan biaya yang cukup besar karena segala sarana harus dipersiapkan. Maka untuk melakukan karya wisata seperti ini perlu disiapkan secara matang dan benar-benar direncakan dengan memperhitungkan segalanya.

2. Masa pelaksanaan karya wisata:

a.Memenuhi tata tertib yang telah ditentukan bersama.

Demi lancarnya acara sesuai dengan apa yang telah direncanakan, maka harus memenuhi tata tertib yang telah ditentukan dengan diperkirakannya pukul berapa waktu berkumpul, pukul berapa berangkat, pukul berapa sampai dengan tujuan, pukul 
berapa terlaksananya acara, serta pukul berapa selesai dan kembali pulang semua hal itu telah dipertimbangkan secara bersama, maka harus mematuhinya. Agar terselenggara sesuai dengan prosedur yang telah ditetapkan. Mengingat perjalaan yang ditempuh ke dari Tanjung Langkat ke Desa Bukit Lawang cukup jauh memakan waktu kurang lebih 2 jam perjalanan. Maka semuanya harus dipertimbangkan dan direncanakan dengan matang-matang. Sehingga apa yang direcanakan dapat berjalan dengan baik sesuai tujuan dilakukannya kunjungan ke situs Goa Kampret di Desa Bukit Lawang.

b.Memberi petunjuk, pengarahan serta penyampaian materi.

Tujuan melakukan kunjungan ke situs Goa Kampret adalah dalam rangka proses pembelajaran maka untuk tercapainya tujuan pembelajaran dengan rencana pelaksanaan pembelajaran yang telah dibuat. Maka siswa/i diberikan petunjuk serta arahan apa yang harus siswa/i lakukan yaitu dengan mendengarkan guru dalam menyampaikan materi yang berkenanaan dengan sejarah situs Goa Kampret dan hubungannya dengan pembelajaran disekolah sesuai amteri zaman praaksara. Hal ini bertujuan agar siswa/i nantinya dapat menjawab lembar kerja siswa yang telah guru berikan.

c. Mengawasi siswa serta siswa harus memenuhi tugas sesuai tanggung jawabnya.

Agar siswa tidak bermain-main pada saat melakukan kunjungan ke situs Goa Kampret siswa harus diawasi karena kondisi Goa Kampret yang sangat gelap, Goa Kampret juga tidak sering didatangi oleh orang maka keadaan didalam Goa Kampret sedikit berbau mistis sehingga siswa tidak diperbolehkan sembarangan bicara yang tidak-tidak sesuai dengan apa yang telah diarahkan sebelumnya. Siswa harus memenuhi tugas sesuai dengan tanggung jawabnya yaitu mematuhi peraturan serta arahan yang sebelumnya telah diberitahukan kepada siswa/i untuk dipatuhi yaitu tidak lupa mencatat/mengingat apa yang telah disampaikan oleh guru. 


\section{Akhir Kegiatan.}

a.Mengadakan diskusi.

Setelah kembali dari melakukan kunjungan ke situs Goa Kampret di Desa Bukit Lawang, Kecamatan Bahorok, Kabupaten Langkat siswa mengadakan diskusi mengenai hasil pengetahuan yang didapat pada saat melakukan kunjungan ke situs Goa Kampret.

b.Mengerjakan tugas serta menarik kesimpulan.

Setelah berdiskusi siswa harus mengerjakan lembar kerja siswa yang telah diberikan oleh guru kemudian menarik kesimpulan dari apa yang telah di dapat dari melakukan kunjungan langsung ke situs Goa Kampret di Desa Bukit Lawang, Kecamatan Bahorok, Kabupaten Langkat. Maka dapat disimpulkan itulah sebabnya disekolah-sekolah jarang atau bahkan tidak pernah membawa siswa/i pergi melakukan perjalanan yang disebut dengan metode karya wisata yaitu belajar diluar kelas dengan membawa siswa kesebuah situs, museum ataupun perkebunan, hal ini disebabkan biaya yang terlalu tinggi dan sangat besar yang nantinya akan memberatkan siswa. Kemudian repotnya atau sulitnya mengkondisikan siswa/i yang jumlahnya banyak pada saat pelaksanaan karya wisata sebab harus diawasi karena kalau tidak siswa tidak akan memikirkan masalah studi atau pelajaran melainkan rekreasi atau jalan-jalnnya. Serta keamanan yang juga sangat penting yaitu kemampuan pisik siswa/i perlu diperhatikan. Itulah sebabnya sehingga kadang apa yang telah direncanakan tidak sesuai apa yang diharapakan. Dengan begitu hasilnya juga tidak sesuai dengan apa yang diharapkan.

\section{Pandangan Siswa terhadap Pemanfaatan Situs Prasejarah Goa Kampret Sebagai Sumber Belajar Sejarah di SMA}

Situs goa kampret memiliki potensi untuk dimanfaatkan sebagai sumber belajar sejarah di Kabupaten Langkat, karena situs goa kampret berkaitan dengan pembelajaran sejarah sesuai Standar Kompetensi: Memahami Prinsip Dasar Ilmu Sejarah, Kompetensi Dasar: Mendeskripsikan Tradisi Sejarah dalam Masyarakat 
Indonesia Masa Praaksara dan Masa Aksara dan Indikator: Mengidentifikasi tradisi masyarakat masa praaksara .

Berdasarkan penelitian yang dilakukan oleh peneliti yaitu melalui penyebaran angket terhadap Siswa SMA Swasta Swakarya yang ada di Kabupaten Langkat yaitu pada siswa SMA kelas X dengan 10 pertanyaan, 4 pilihan diantaranya adalah pilihan Sangat Setuju (SS), Setuju (ST), Kurang Setuju (KS), Tidak Setuju (TS). Berdsarkan dari hasil angket yang disebarkan ke siswa SMA Swasta Swakarya dapat diketahui bahwa ada 21 orang siswa yang menyatakan sangat setuju dengan hasil presentasi $70 \%$ dan 9 orang siswa yang menyatakan setuju dengan hasil presentasi 30\%. Dari penjelasan diatas maka dapat dianalisis bahwa situs goa kampret sangat tinggi presentasinya untuk dapat dijadikan sebagai sumber belajar sejarah lokal di Kabupaten Langkat. Maka dapat dilihat bahwa situs goa kampret memiliki potensi untuk dimanfaatkan sebagai sumber belajar sejarah bagi siswa SMA di Kabupaten Langkat.

Dari setiap penjelasan pada tabel angket penelitian dapat dianalisis dan disimpulkan bahwa situs Goa Kampret sangat bermanfaat untuk dijadikan sebagai sumber belajar sejarah bagi siswa SMA di Kabupaten Langkat karena dengan melakukan kunjungan langsung ke situs Goa Kampret selain mendukung untuk proses belajar mengajar hal ini juga diharapkan dapat menanamkan kecintaan dalam hati siswa bahwa peninggalan prasejarah itu sangat penting maka dari itu penting untuk dilestarikan sehingga dapat diketahui oleh masyarakat luas.

Hal ini juga sesuai K13 dibuktikan berdasarkan silabus, Situs Goa Kampret ini masuk kedalam KD Memahami Prinsip Dasar Ilmu Sejarah dengan Kompetensi dan Indikator Pencapaian: Mengidentifikasi Tradisi Masyarakat Pada Masa Praaksara. Mengingat Goa Kampret merupakan goa yang memiliki peninggalan masa mesolitik sampai dengan neolitik dengan ditemukannya sebuah peninggalan berupa kapak batu (masa mesolitik) beserta gerabah (masa neolitik), sehingga dari hasil tersebut diketahui bahwa goa ini pernah menjadi aktifitas manusia pada masa lampau yaitu dengan ciri artefak yang ditinggalkan menunjukkan ciri budaya hoabinh. 
Berdasarkan penelitian yang dilakukan oleh peneliti dari hasil LKS dapat disimpulkan bahwa 11 siswa dengan presentasi $37 \%$ mendapat skor nilai sangat baik. Dan 13 siswa dengan presentasi 43\% mendapat skor nilai baik. Dan 6 siswa dengan presentasi $20 \%$ mendapat skor cukup baik. Sehingga dapat disimpulkan nilai rata-rata adalah 70 dan nilai tertinggi adalah 94 kemudian nilai terendah adalah 65. Dilihat dari kriteria penilaian dengan syarat ketuntasan harus mencapai nilai skor 70, maka dapat dilihat pada tabel diatas 24 orang siswa dikatakan lulus dan 6 orang siswa tidak lulus. Berdasarkan hasil presentasi ternyata banyak siswa yang lulus mencapai ketuntasan dari pada siswa yang tidak lulus. Dalam hal ini secara keseluruhan dapat disimpulkan bahwa pengetahuan siswa mencapai nilai rata-rata. Dari data tersebut dapat disimpulkan bahwa 11 siswa dengan presentasi $37 \%$ mendapat skor nilai sangat baik. Dan 13 siswa dengan presentasi 43\% mendapat skor nilai baik. Dan 6 siswa dengan presentasi $20 \%$ mendapat skor cukup baik. Sehingga dapat disimpulkan nilai rata-rata adalah 70 dan nilai tertinggi adalah 94 kemudian nilai terendah adalah 65 .

Dilihat dari kriteria penilaian dengan syarat ketuntasan harus mencapai nilai skor 70, maka dapat dilihat pada tabel diatas 24 orang siswa dikatakan lulus dan 6 orang siswa tidak lulus. Berdasarkan hasil presentasi ternyata banyak siswa yang lulus mencapai ketuntasan dari pada siswa yang tidak lulus. Dalam hal ini secara keseluruhan dapat disimpulkan bahwa pengetahuan siswa mencapai nilai rata-rata.

Dan dari paparan diatas dapat dianalisis, setelah hasil lembar kerja siswa telah selesai dikerjakan oleh siswa SMA Swasta Swakarya kelas X sebanyak 30 orang siswa, maka untuk mengetahui hasilnya apakah situs Goa Kampret dapat dimanfaatkan sebagai sumber belajar sejarah bagi siswa SMA sesuai K13, akan peneliti lihat ketuntasannya berdasarkan kriteria penilaian: kriteria indikator skor yang diperoleh dari skor 45 s/d 100, nilai kulitatif sangat baik, baik, cukup, atau kurang cukup, serta nilai kuantitatif $1 \mathrm{~s} / \mathrm{d} 4$ yang telah dibuat pada rencana pelaksanaan pemebelajaran berapa orang siswa yang dikatakan lulus dan berapa orang siswa yang tidak lulus tidak mencapai nilai 70 yang di bahas pada poin selanjutnya tentang pendapat siswa terhadap 
pemanfaatan situs prasejarah Goa Kampret sebagai sumber belajar sejarah bagi siswa SMA Swasta Swakarya sesuai K13 di Kabupaten Langkat secara lebih rinci.

Dari setiap penjelasan pada tabel angket penelitian dan berdasarkan hasil lebar kerja siswa dapat dianalisis bahwa situs prasejarah Goa Kampret dapat dimanfaatkan sebagai sumber belajar sejarah bagi siswa SMA di Kabupaten Langkat untuk tercapainya pembelajaran yang efektif dan maksimal. Maka dapat disimpulkan bahwa pemanfaatan situs prasejarah Goa Kampret sebagai sumber belajar sejarah merupakan salah satu sumber yang baik dalam mengembangkan kreativitas siswa dan mempermudah memahami pembelajaran sejarah dengan baik melalui berkunjung langsung ke situs Goa Kampret.

Oleh sebab itu, pentingnya sebuah situs sebagai sumber belajar sejarah yaitu untuk menambah wawasan berpikir para siswa. Kehadiran situs ini sangat perlu ditingkatkan pada zaman sekarang ini, mengingat banyaknya generasi muda khususnya para anak didik yang kurang peduli terhadap peninggalan bersejarah. Selain itu, dengan melihat langsung bukti peninggalan sejarah tersebut maka akan lebih mudah bagi siswa untuk memahaminya.

Tujuan pemanfaatan sumber belajar ini agar siswa menambah wawasan dalam materi tersebut serta mengapresiasikan bahwa di Kabupaten Langkat terdapat beberapa peninggalan prasejarah. Dan menjadikan hal tersebut sebagai pengalaman berharga. Karena berdasarkan hasil angket hasilnya $80 \%$ positif.

Menurut analisis penulis bahwa penggunaan situs Goa Kampret sebagai sumber belajar sejarah merupakan salah satu sumber yang baik dalam mengembangkan kreativitas siswa dan mempermudah memahami pembelajaran sejarah dan merubah menset siswa bahwa belajar sejarah itu tidak membosankan melinkan sangat menyenangkan. Kehadiran sebuah situs prasejarah sangat perlu ditingkatkan pada zaman sekarang ini, mengingat banyaknya generasi muda khususnya para anak didik yang kurang peduli terhadap peninggalan bersejarah. 


\section{PENUTUP}

Goa kampret merupakan tempat aktifitas manusia pada masa praksara pada zaman mesolitik sampai ke neolitik dibuktikan dengan ditemukannya artefak, tulang serta gerabah dan memiliki ciri berbudaya hoabinh. Mengingat pada zaman praaksara manusia sering bertempat tinggal di goa-goa dan pinggir pantai serta hidup berpindahpindah. Goa kampret tergolong pada periode masa mesolitik sampai ke masa neolitik. Hal ini dibuktikan dengan ditemukannya artefak yang menunjukkan ciri budaya mesolitik (kapak batu) sampai kepada ciri budaya neolitik (gerabah). Selain itu sebaran situs ini diindikasikan berbudaya Hoabinh dengan ditemukannya artefak batu yang ditemukan di permukaan situs.

Cara memanfaatkan Situs Goa Kampret sebagai sumber belajar sejarah bagi siswa SMA Swasta Swakarya sesuai KTSP di Kabupaten Langkat adalah dengan membawa siswa/siswi SMA Swasta Swakarya di Tanjung Langkat melakukan kunjungan langsung ke situs Goa Kampret di Desa Bukit Lawang dengan melakukan pembelajaran dengan metode karyawisata agar penggunaan metode karya wisata dapat efektif, maka pelaksanaannya perlu memperhatikan langkah-langkah sebagai berikut: Pertama, masa persiapan guru harus matang. Kedua, Masa pelaksanaan karya wisata; memenuhi tata tertib yang telah ditentukan. Dan Ketiga, masa kembali dari karya wisata; mengadakan diskusi mengenai segala hal hasil dari karya wisata, Mengerjakan tugas serta menarik kesimpulan yang diperoleh.

Pendapat siswa terhadap pemanfaatan situs prasejarah Goa Kampret sebagai sumber belajar sejarah di Kabupaten Langkat ialah dari hasil presentasi angket penelitian dapat diketahui bahwa 21 orang siswa yang menyatakan sangat setuju dengan hasil presentasi tertarik mengunjungi situs Goa Kampret. Dan berdasarkan hasil dari LKS disimpulkan 30 orang siswa siswa lebih senang belajar di luar sekolah dengan melakukan kunjungan langsung ke situs Goa Kampret. Mengingat dilihat dari sejarah Situs Goa Kampret masuk kedalam Indikator Pencapaian: Mengidentifikasi Tradisi Masyarakat Pada Masa Praaksara. 


\section{Referensi}

Ketut Wiradnyana, dkk. 1998. Laporan Penelitian Arkeologi Survey Gua-gua di Bukit Lawang dan Sekitarnya, Kecamatan Bahorok, Kabupaten Langkat, Provinsi Sumatera Utara. Medan : BALAR

Ketut Wiradnyana, dkk. 1999. Laporan Penelitian Arkeologi Ekskavasi situs Gua Kampret Tahap II di Desa Bukit Lawang Kec. Bahorok, Kab.Langkat, Sumatera Utara. Medan : BALAR

Mulyasa. 2013. Pengembangan dan Implementasi Kurikulum 2013. Bandung : PT Remaja Rosdakarya

Muzamiroh, Mida Latifatul. 2013. Kupas Tuntas Kurikulum 2013: Kelebihan dan kekurangan kurikulum 2013. Kata Pena

Roestiyah. 2008. Strategi Belajar Mengajar. Jakarta: Rineka Cipta

Sanjaya, Wina. 2011. Strategi Pembelajaran Berorientasi Standar Proses Pendidikan. Jakarta : Kencana

Syaiful Bahri Djamarah dan Aswan Zain. 2010. Strategi Belajar Mengajar. Jakarta: Rineka Cipta

Undang-undang Republik Indonesia Nomor 11 Tahun 2010 Tentang Cgar Budaya

Wiradnyana, Ketut. 2011. Pra Sejarah : Sumatera Bagian Utara Kontribusinya pada Kebudayaan Masa Kini. Jakarta : Yayasan Pustaka Obor Indonesia 